\title{
The First Two Decades of Smart City Research from a Risk Perspective
}

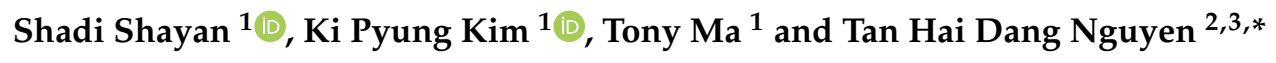 \\ 1 UniSA STEM, University of South Australia, Adelaide, SA 5000, Australia; \\ shadi.shayan@mymail.unisa.edu.au (S.S.); ki.kim@unisa.edu.au (K.P.K.); tony.ma@unisa.edu.au (T.M.) \\ 2 Institute of Research and Development, Duy Tan University, Danang 550000, Vietnam \\ 3 Faculty of Civil Engineering, Duy Tan University, Danang 550000, Vietnam \\ * Correspondence: nguyenthaidang@duytan.edu.vn; Tel.: +84-905-393-727
}

Received: 9 October 2020; Accepted: 5 November 2020; Published: 9 November 2020

\begin{abstract}
Although they offer major advantages, smart cities present unprecedented risks and challenges. There are abundant discrete studies on risks related to smart cities; however, such risks have not been thoroughly understood to date. This paper is a systematic review that aims to identify the origin, trends, and categories of risks from previous studies on smart cities. This review includes 85 related articles published between 2000 and 2019. Through a thematic analysis, smart city risks were categorized into three main themes: organizational, social, and technological. The risks within the intersections of these themes were also grouped into (1) digital transformation, (2) socio-technical, and (3) corporate social responsibility. The results revealed that risk is a comparatively new topic in smart-city research and that little focus has been given to social risks. The findings indicated that studies from countries with a long history of smart cities tend to place greater emphasis on social risks. This study highlights the significance of smart city risks for researchers and practitioners, providing a solid direction for future smart-city research.
\end{abstract}

Keywords: smart city; risk; systematic literature review; urbanization

\section{Introduction}

Urbanization is defined as a multidimensional process in which large numbers of people rapidly and permanently concentrate in a relatively small geographic area to form cities [1]. Such rapid growth is the underlying source of urban issues, due to the additional pressure on urban infrastructure and natural resources [2]. The sustainable social, economic, and environmental development of cities and the provision of adequate resources for citizens can become a real challenge for governments [3]. Thus, governments and city authorities are now considering novel approaches to meet citizens' demands, focusing on the efficient utilization of resources while minimizing adverse impacts on the natural environment [4]. Approaches for a green city, sustainable city, carbon-neutral city, and smart city have been introduced to revolutionize the use of natural resources and urban infrastructure to address urbanization problems [5]. The smart-city concept-the latest trend-integrates information technologies into urban areas, to overcome urban challenges, improve sustainability in cities, and enhance citizens' quality of life [6].

The concept of a smart city was first introduced in the 1990s [7]. Since then, various scholars and industrial bodies have tried to develop a proper smart-city definition. Although there has not been a clear and comprehensive definition of a smart city established, some common characteristics exist among all smart cities. Nam and Pardo [8] emphasized that the smart city should consider technology, human, and institutional factors as its core components. Bergh and Viaene [9] further defined a smart city by suggesting two main types of a smart city: (1) technology-oriented infrastructure-intensive 
city, such as Seoul in South Korea and Santander in Spain; and (2) citizen-oriented city, such as Montreal in Canada and Amsterdam in Netherland. The principal features of any smart city consist of integrating digital technology into urban areas, involving residents in policymaking, emphasizing environmental sustainability, and utilizing entrepreneurship and human capital for urban development [10]While technology is regarded as a hardware and software infrastructure, the human element comprises social capital, diversity, and collective intelligence. The institutional factor addresses smart-city governances, policies, and regulations. There is a census among researchers about what a smart city should consider and improve, which are technological advancements and improved human well-being. Subsequently, another research defines a smart city based on six dimensions: smart people, smart living, smart governance, smart mobility, smart environment, and smart economy [11].

In alignment with smart city research and studies, currently, 250 smart-city development projects in 178 cities are being undertaken worldwide [12]. Two major approaches exist to develop a smart city: (a) New Smart City Development and (b) Traditional City Transforming. The first approach is to develop a new smart city from scratch on vacant lands. The most recognized cases of this type are New Songdo in South Korea and Masdar in the United Arab Emirates. For example, the New Songdo smart city has no food rubbish bins and trucks on the roads, since all food wastes from kitchens are directly conveyed to the food-waste processing center, without leaving any environmentally non-friendly footprints. In the Masdar smart city, autonomous shuttle services and rapid charging stations for electric vehicles are used for smart transportation. The second approach, which is currently more frequently adopted, is to upgrade an existing traditional city and transform it into a smart city. Some well-recognized examples of this type of development are Singapore and Barcelona. Singapore has developed a platform that bundles all government services from different departments for citizens in a single mobile phone application, and Barcelona implemented wireless sensors in the undersurface of roads to show empty parking spaces, in real time, to drivers, via a mobile phone application.

While the above examples explicitly illustrate some benefits of smart cities, there are more considerable advantages for smart cities, including effective data-driven decision-making, enhanced citizen engagement, safer communities, reduced environmental footprint, and economic prosperity [13-15]. The real-time information collected through electronic sensors and connected devices allows the city authorities to make well-informed decisions. Collaboration tools, such as mobile phone applications and web portals, help citizens provide their viewpoints directly to the government and improve citizen involvementOther technologies, such as surveillance cameras, car license plate recognition, and gunshot detectors, can increase security and provide a safer place for communities. Deployment of air-quality monitoring sensors and smart waste-collection technologies reduce the adverse impacts on the natural environment. Lastly, the private sector partnership with governments in smart-city projects can increase economic development opportunities.

Although they present outstanding opportunities, the incorporation of advanced technologies into urban systems introduces new risks and issues, such as unequal access to smart-city data, a high cost of implementation and maintenance, and an increase in potential cyber-attacks [16]. Shifting a well-established urban system to a smart city is a complex and fundamental change. Addressing these issues calls for a robust plan that incorporates a rigorous risk-management framework [17]. Nevertheless, technology has been significantly overtaking innovations in risk-management and governance methods. Therefore, the integration of advanced risk-management practices into planning stages will ensure the long-term resilience of smart cities [16]. The implementation of effective risk-management processes can mitigate risks and assist governments in proactively dealing with the challenges arising from urban transformation [18]. The value of risk management in smart-city transformation processes has been emphasized by researchers, industry standards, best practices, and International Organization for Standardization (ISO 37106) $[7,18,19]$. However, a question remains unanswered: What are the risks of smart cities?

Despite a significant number of relevant studies in the literature, actual inclusive evidence for smart-city risks has not been provided and comprehensively identified and understood. A systematic literature review is a valuable research technique to identify, evaluate, and summarize all relevant 
publications about smart city risks and challenges [20]. Several reviews have been undertaken on smart-city topics, such as the governance components of smart cities [21], the indicators of smart cities [22], the results of smart city development [20], and, more recently, the application of fog computing in smart cities [23]. However, no comprehensive review has analyzed smart-city risks. The present study attempts to address this gap by reviewing the existing literature to identify the emergence, trends, and categories of risk in smart-city research studies over the past two decades. The results will provide a solid evidence-based direction for future research on smart-city risk management, as well as a practical guide for urban decision-makers to deal with relevant risks.

The remaining sections of this paper are organized as follows. Section 2 explains the research procedures and methods used to select the relevant studies. Section 3 provides the results of the systematic literature review, outlining the evolution of research on smart-city risks over the past two decades and presenting the themes emerging from the existing literature. In Section 4, the characteristics of the results are explained and discussed in relation to the identified themes. The paper concludes with a summary of the main findings, along with a discussion about the limitations and implications of the study in Section 5 .

\section{Materials and Methods}

The purpose of this research is to identify and categorize smart-city risks, as well as determine overlooked areas in the current literature, from a risk perspective. A systematic review can bring this scattered knowledge together and provide an overview of work that has been carried out in this area; this is a comprehensive, transparent, and reproducible technique that can be used to create new knowledge from previous research on a particular topic [24]. Based on the Preferred Reporting Items for Systematic reviews and Meta-Analysis (PRISMA) framework and previous systematic literature reviews [25-28], this study's research process was developed as shown in Figure 1. In particular, the PRISMA framework was adopted because it enables researchers to conduct a systematic review and critically assess, collect, and analyze relevant research, studies, and the existing literature. 


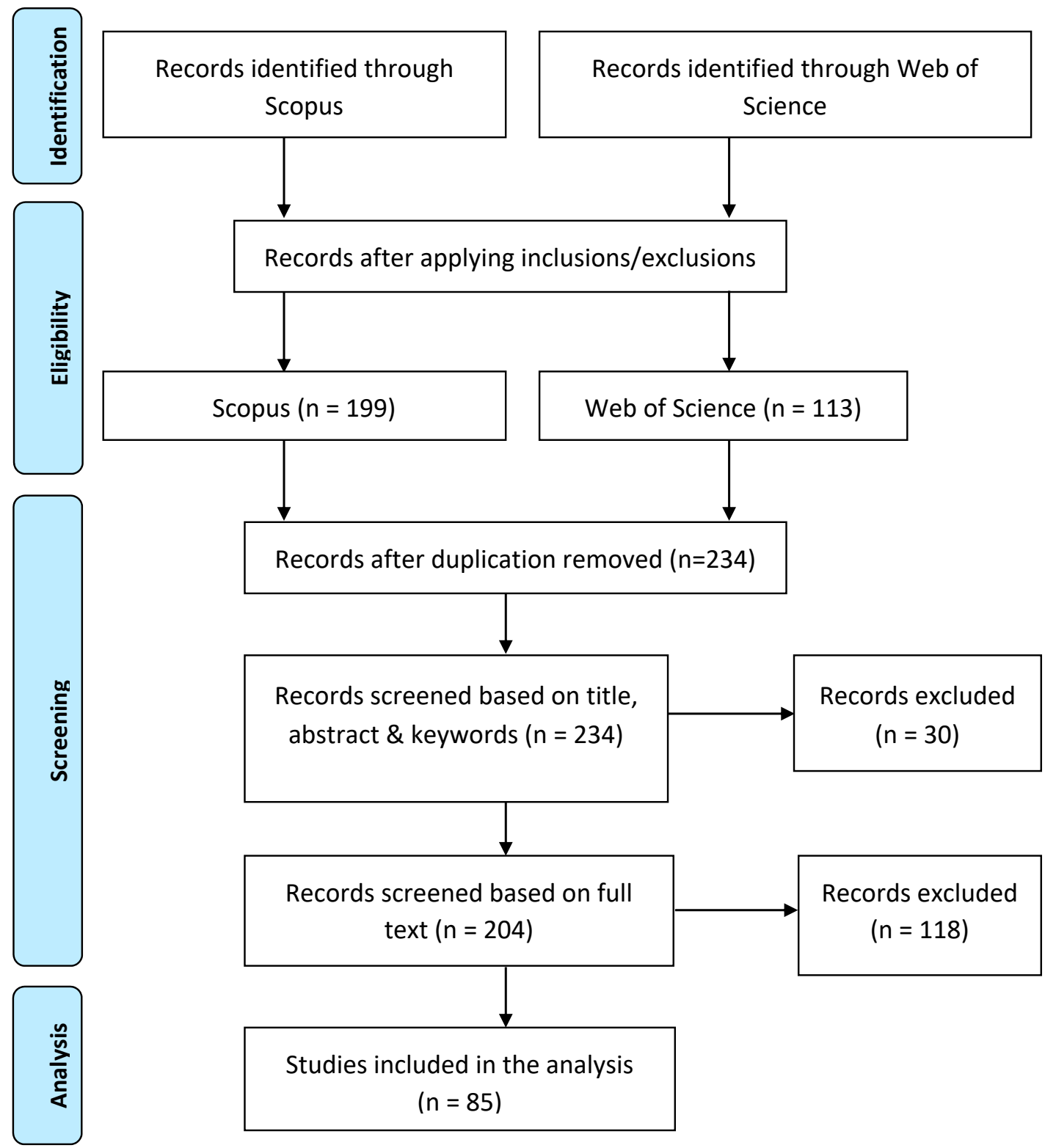

Figure 1. Systematic-literature-review framework.

\subsection{Phase 1: Identification}

The first stage of this review was the formulation of the problem, including the development of the research question and research aim and establishment of the research protocol and criteria [29]. The purpose of this study was clearly defined and discussed in the introduction section. A detailed protocol was structured to search the body of knowledge and achieve the research aim. The initial search was conducted in December 2019, using electronic databases, including Scopus and Web of Science. Since Scopus is the largest source of peer-reviewed articles, sourcing from more than 5000 publishers in various areas, it was a suitable database to search for this study [30]. Web of Science also includes more than 9000 of the most impactful journals across 178 disciplines, which encompasses over 35 million records [31].

To obtain the most relevant and accurate results, the following collection of keywords was used with the "OR" Boolean connector: "smart city", "smart cities", "digital city", "intelligent city", "information city", "ubiquitous city", and "wired city". An "AND" Boolean connector was used to include the "risk" keyword and create an additional search string. Since the smart city concept was first 
introduced in the late 1990s and early 2000s [32], any publication before 2000 was excluded, and the search was limited to the papers published between 2000 and 2019. This resulted in a substantial number of articles, including 792 papers obtained through Scopus and 246 documents from the Web of Science.

\subsection{Phase 2: Eligibility}

In this stage, adequate inclusion/exclusion criteria were outlined to ensure that the research question boundaries were distinctly defined [33]. Table 1 outlines these inclusion/exclusion criteria, which were utilized as a checklist throughout the research process.

Table 1. Systematic literature review inclusion and exclusion criteria.

\begin{tabular}{ccc}
\hline Criteria & Inclusions & Exclusions \\
\hline Criteria 1 & Articles must be published between 2000 to 2019 & Any articles outside the designated date \\
\hline Criteria 2 & Articles must be published in English & Any articles in other languages \\
\hline Criteria 3 & The source type of publications must be a journal & $\begin{array}{c}\text { Any conference proceedings, books/book } \\
\text { chapters, editorials, notes, trade publications, } \\
\text { and letters }\end{array}$ \\
\hline Criteria 4 & Articles must be published in a peer-reviewed journal & Any articles in non-peer-reviewed journals \\
\hline
\end{tabular}

Any publication in a language other than English was eliminated from further review. In addition, the search was restricted to peer-reviewed journal articles, to ensure the quality and reliability of the publications [30]. The outcome of this refinement process was 199 articles gathered from Scopus and 113 papers gathered from the Web of Science.

\subsection{Phase 3: Screening}

In the screening phase, the reviewers decided which studies should be considered for review. The first step in the screening process was to remove duplications of articles, which led to a total number of 234 peer-reviewed journal articles from both databases for further investigation to assess their relevance to the research question [34]. The titles, abstracts, and keywords of the articles were then manually screened, to exclude irrelevant papers. Some of the papers were eliminated because they were outside the scope of this research (e.g., smartphone, smart toys, smart home, chronic disease risk, and cancer risks), and this process resulted in the identification of 30 irrelevant articles. The authors then carefully read the full texts of the remaining 204 studies, to ensure the alignment of the articles with the research question. The focus of this reading was to identify the types of risks in smart cities. At the end of the screening process, only 85 papers met the inclusion and exclusion criteria, which are listed in Table 2.

\subsection{Phase 4: Analysis}

In this stage of the review process, information was systematically taken from the remaining 85 articles, for a quantitative and then a thematic analysis. The former involved considering each article as a separate case that has a particular variable, such as publication date, context, and method [35]. The latter analysis included mapping all the information provided within the articles, to identify research gaps in the smart-city risk and provide an outline for future research. In a broad sense, the thematic analysis involved the processes of reading the selected literature and extracting their common themes [36]. All 85 articles were read thoroughly and in detail, to extract their mutual themes. 
Table 2. List of included articles.

\begin{tabular}{|c|c|c|c|c|c|c|c|c|c|c|}
\hline \multirow[t]{2}{*}{ No. } & \multirow[t]{2}{*}{ Reference } & \multirow[t]{2}{*}{ Context } & \multicolumn{5}{|c|}{ Research Method } & \multicolumn{3}{|c|}{ Risk Categories (Theme) } \\
\hline & & & Quantitative & Qualitative & Mixed & Empirical & Theoretical & Organizational & Technological & Social \\
\hline 1 & Viitanen and Kingston [37] & UK & & & & & $\sqrt{ }$ & $\sqrt{ }$ & & \\
\hline 2 & Beart [38] & UK & & & & $\sqrt{ }$ & & & $\sqrt{ }$ & \\
\hline 3 & Mehmood et al. [39] & UK & & & & $\sqrt{ }$ & & & $\sqrt{ }$ & \\
\hline 4 & Roza et al. [40] & UK & & & $\sqrt{ }$ & & & & $\sqrt{ }$ & \\
\hline 5 & McGuire [41] & UK & & & & & $\sqrt{ }$ & & & $\sqrt{ }$ \\
\hline 6 & Ahmad et al. [42] & UK & & & & $\sqrt{ }$ & & & $\sqrt{ }$ & \\
\hline 7 & Amankwaa and Blay [43] & UK & & $\sqrt{ }$ & & & & & & $\sqrt{ }$ \\
\hline 8 & Ahmad et al. [44] & UK & & & & $\sqrt{ }$ & & & $\sqrt{ }$ & \\
\hline 9 & Alandjani [45] & UK & & & & $\sqrt{ }$ & & & $\sqrt{ }$ & \\
\hline 10 & Vitunskaite et al. [46] & UK & & $\sqrt{ }$ & & & & & $\sqrt{ }$ & \\
\hline 11 & Urquhart et al. [47] & UK & & & & & $\sqrt{ }$ & & $\sqrt{ }$ & \\
\hline 12 & Kitchin and Dodge [48] & UK & & & & & $\sqrt{ }$ & & $\sqrt{ }$ & \\
\hline 13 & Javidroozi et al. [49] & UK & & $\sqrt{ }$ & & & & $\sqrt{ }$ & & \\
\hline 14 & Goldhill [50] & UK & & & & & $\sqrt{ }$ & & & $\sqrt{ }$ \\
\hline 15 & Avgerou et al. [51] & USA & & $\sqrt{ }$ & & & & & $\sqrt{ }$ & \\
\hline 16 & Saaty and De Paola [52] & USA & & & & & $\sqrt{ }$ & $\sqrt{ }$ & & \\
\hline 17 & Li and Shahidehpour [53] & USA & & & & & $\sqrt{ }$ & & $\sqrt{ }$ & \\
\hline 18 & Ghosh and Gosavi [54] & USA & & & & $\sqrt{ }$ & & $\sqrt{ }$ & & \\
\hline 19 & Michelfelder [55] & USA & & & & & $\sqrt{ }$ & & & $\sqrt{ }$ \\
\hline 20 & Falco et al. [56] & USA & & & & $\sqrt{ }$ & & & $\sqrt{ }$ & \\
\hline 21 & Soyata et al. [57] & USA & & & & $\sqrt{ }$ & & & $\sqrt{ }$ & \\
\hline 22 & Safransky [58] & USA & & $\sqrt{ }$ & & & & $\sqrt{ }$ & & \\
\hline 23 & Means [59] & USA & & $\sqrt{ }$ & & & & & & $\sqrt{ }$ \\
\hline 24 & He and Chow [60] & USA & & & & $\sqrt{ }$ & & & $\sqrt{ }$ & \\
\hline 25 & Eskridge [61] & USA & & & & & $\sqrt{ }$ & $\sqrt{ }$ & & \\
\hline 26 & Juntao and Quanyan [62] & USA & & & & & $\sqrt{ }$ & & $\sqrt{ }$ & \\
\hline 27 & Al Shidhani [63] & USA & & & & $\sqrt{ }$ & & & $\sqrt{ }$ & \\
\hline 28 & Zhu and Zuo [64] & China & & & & & $\sqrt{ }$ & & $\sqrt{ }$ & \\
\hline 29 & Xu et al. [65] & China & & & & $\sqrt{ }$ & & & $\sqrt{ }$ & \\
\hline 30 & Hasan et al. [66] & China & & & & $\sqrt{ }$ & & & $\sqrt{ }$ & \\
\hline 31 & Anwar et al. [67] & China & & & $\sqrt{ }$ & & & $\sqrt{ }$ & & \\
\hline 32 & Wu et al. [68] & China & & & & & $\sqrt{ }$ & $\sqrt{ }$ & & \\
\hline 33 & Wang et al. [69] & China & & & & & $\sqrt{ }$ & $\sqrt{ }$ & & \\
\hline
\end{tabular}


Table 2. Cont.

\begin{tabular}{|c|c|c|c|c|c|c|c|c|c|c|}
\hline \multirow[t]{2}{*}{ No. } & \multirow[t]{2}{*}{ Reference } & \multirow[t]{2}{*}{ Context } & \multicolumn{5}{|c|}{ Research Method } & \multicolumn{3}{|c|}{ Risk Categories (Theme) } \\
\hline & & & Quantitative & Qualitative & Mixed & Empirical & Theoretical & Organizational & Technological & Social \\
\hline 34 & Li et al. [70] & China & & & & & $\sqrt{ }$ & & $\sqrt{ }$ & \\
\hline 35 & Nyothiri et al. [71] & China & & & & $\sqrt{ }$ & & & $\sqrt{ }$ & \\
\hline 36 & Elahi et al. [72] & China & $\sqrt{ }$ & & & & & $\sqrt{ }$ & & \\
\hline 37 & Di Bella et al. [73] & Italy & & & & $\sqrt{ }$ & & & & $\sqrt{ }$ \\
\hline 38 & Bartoli et al. [74] & Italy & & & & $\sqrt{ }$ & & & $\sqrt{ }$ & \\
\hline 30 & Comodi et al. [75] & Italy & & & $\sqrt{ }$ & & & $\sqrt{ }$ & & \\
\hline 40 & Trivellato [76] & Italy & & $\sqrt{ }$ & & & & & & $\sqrt{ }$ \\
\hline 41 & Beretta [77] & Italy & & $\sqrt{ }$ & & & & & & $\sqrt{ }$ \\
\hline 42 & Anjum et al. [78] & Italy & & & & $\sqrt{ }$ & & & $\sqrt{ }$ & \\
\hline 43 & De Nicola et al. [79] & Italy & & & & $\sqrt{ }$ & & $\sqrt{ }$ & & \\
\hline 44 & Sharma and Singh [80] & India & & & & & $\sqrt{ }$ & $\sqrt{ }$ & & \\
\hline 45 & Hayat [81] & India & & $\sqrt{ }$ & & & & $\sqrt{ }$ & & \\
\hline 46 & Dhyani et al. [82] & India & & $\sqrt{ }$ & & & & $\sqrt{ }$ & & \\
\hline 47 & Bashir and Mir [83] & India & & & & & $\sqrt{ }$ & & $\sqrt{ }$ & \\
\hline 48 & Mustafa and Kar [84] & India & $\sqrt{ }$ & & & & & $\sqrt{ }$ & & \\
\hline 49 & Malik and Singh [85] & India & & & & $\sqrt{ }$ & & & $\sqrt{ }$ & \\
\hline 50 & Shin [86] & Korea & $\sqrt{ }$ & & & & & & & $\sqrt{ }$ \\
\hline 51 & Lee et al. [87] & Korea & & & & & $\sqrt{ }$ & & $\sqrt{ }$ & \\
\hline 52 & Israr et al. [88] & Korea & & & & & $\sqrt{ }$ & $\sqrt{ }$ & & \\
\hline 53 & Park [89] & Korea & & & & & $\sqrt{ }$ & $\sqrt{ }$ & & \\
\hline 54 & Ullah et al. [90] & Korea & & & & & $\sqrt{ }$ & $\sqrt{ }$ & & \\
\hline 55 & Lee [91] & Korea & & & & $\sqrt{ }$ & & & & $\sqrt{ }$ \\
\hline 56 & Galdon-Clavell [92] & Spain & & & & & $\sqrt{ }$ & & & $\sqrt{ }$ \\
\hline 57 & Sánchez Bernabeu et al. [93] & Spain & & & & $\sqrt{ }$ & & & $\sqrt{ }$ & \\
\hline 58 & Rebollo-monedero et al. [94] & Spain & & & & $\sqrt{ }$ & & & $\sqrt{ }$ & \\
\hline 59 & Mulero et al. [95] & Spain & & $\sqrt{ }$ & & & & & $\sqrt{ }$ & \\
\hline 60 & Grimaldi et al. [96] & Spain & & $\sqrt{ }$ & & & & & & $\sqrt{ }$ \\
\hline 61 & Vassilaras and Yovanof [97] & Greece & & & & & $\sqrt{ }$ & & $\sqrt{ }$ & \\
\hline 62 & Coccossis et al. [98] & Greece & & $\sqrt{ }$ & & & & $\sqrt{ }$ & & \\
\hline 63 & Spiliotis et al. [99] & Greece & & & & $\sqrt{ }$ & & & $\sqrt{ }$ & \\
\hline 64 & Moustaka et al. [100] & Greece & & $\sqrt{ }$ & & & & & $\sqrt{ }$ & \\
\hline 65 & Vu and Hartley [101] & Singapore & $\sqrt{ }$ & & & & & $\sqrt{ }$ & & \\
\hline 66 & Hazel Si Min [102] & Singapore & & $\sqrt{ }$ & & & & & $\sqrt{ }$ & \\
\hline 67 & Hazel Si Min [103] & Singapore & & & & & $\sqrt{ }$ & & $\sqrt{ }$ & \\
\hline 68 & $\begin{array}{c}\text { Ranchordás and } \\
\text { Goanta [104] }\end{array}$ & $\begin{array}{l}\text { The } \\
\text { Netherlands }\end{array}$ & & & & & $\sqrt{ }$ & $\sqrt{ }$ & & \\
\hline
\end{tabular}


Table 2. Cont

\begin{tabular}{|c|c|c|c|c|c|c|c|c|c|c|}
\hline \multirow[t]{2}{*}{ No. } & \multirow[t]{2}{*}{ Reference } & \multirow[t]{2}{*}{ Context } & \multicolumn{5}{|c|}{ Research Method } & \multicolumn{3}{|c|}{ Risk Categories (Theme) } \\
\hline & & & Quantitative & Qualitative & Mixed & Empirical & Theoretical & Organizational & Technological & Social \\
\hline 69 & Brous et al. [105] & $\begin{array}{l}\text { The } \\
\text { Netherlands }\end{array}$ & & $\sqrt{ }$ & & & & $\sqrt{ }$ & & \\
\hline 70 & Seto [106] & Japan & & & & $\sqrt{ }$ & & & $\sqrt{ }$ & \\
\hline 71 & Sasaki et al. [107] & Japan & & & & & $\sqrt{ }$ & & $\sqrt{ }$ & \\
\hline 72 & Norton et al. [108] & France & & & $\sqrt{ }$ & & & $\sqrt{ }$ & & \\
\hline 73 & Thibaud et al. [109] & France & & & & & $\sqrt{ }$ & $\sqrt{ }$ & & \\
\hline 74 & Jaïdi et al. [110] & Tunisia & & & & $\sqrt{ }$ & & & $\sqrt{ }$ & \\
\hline 75 & Bennati et al. [111] & Switzerland & & & & $\sqrt{ }$ & & & $\sqrt{ }$ & \\
\hline 76 & Alandjani [45] & $\begin{array}{l}\text { Saudi } \\
\text { Arabia }\end{array}$ & & & & $\sqrt{ }$ & & & $\sqrt{ }$ & \\
\hline 77 & Leszczynski [112] & $\begin{array}{c}\text { New } \\
\text { Zealand }\end{array}$ & & & & & $\sqrt{ }$ & $\sqrt{ }$ & & \\
\hline 78 & White [113] & Ireland & & & & & $\sqrt{ }$ & & & $\sqrt{ }$ \\
\hline 79 & Pető and Tokody [114] & Hungry & & & & & $\sqrt{ }$ & & $\sqrt{ }$ & \\
\hline 80 & Krämer et al. [115] & Germany & & & & $\sqrt{ }$ & & & $\sqrt{ }$ & \\
\hline 81 & Toapanta et al. [116] & Ecuador & & & & & $\sqrt{ }$ & & $\sqrt{ }$ & \\
\hline 82 & Gulsrud et al. [117] & Denmark & & $\sqrt{ }$ & & & & & & $\sqrt{ }$ \\
\hline 83 & Austin and Lie [118] & Canada & & $\sqrt{ }$ & & & & & $\sqrt{ }$ & \\
\hline 84 & Yang and Xu [119] & Australia & & & & & $\sqrt{ }$ & $\sqrt{ }$ & & \\
\hline 85 & Steyaert [120] & Belgium & $\sqrt{ }$ & & & & & $\sqrt{ }$ & & \\
\hline Total & & & 5 & 18 & 4 & 27 & 31 & 28 & 43 & 14 \\
\hline
\end{tabular}

The $\sqrt{ }$ specifies the research methods and risk categories of the papers. The bold is to emphasize on this row since it shows the total number of papers in each category. 


\section{Results}

The selected studies have a wide range of diversity among publication years, context, and research methods. For the quantitative analysis, data from the identified articles were summarized in a numerical format, according to their publication date, country, and research method [121]. The articles were also thematically analyzed to identify their common themes and categories. To achieve this goal, the authors labeled the recorded articles based on their proposed smart-city risks and classified them into three different categories, namely technological risks, organizational risks, and social risks [122].

\subsection{Quantitative Analysis}

The descriptive statistics for the 85 identified articles are shown in Table 2. This table outlines the quantitative data, including publication date, context, and method. The publication trend from 2000 to 2019 is depicted in Figure 2. The table and the graph collectively reveal that the oldest study was conducted in 2000 and that the number of articles has gradually increased since 2012. The figure shows that more than $65 \%$ of the articles were published in the last two years, and almost $90 \%$ of the studies were published in the last five years. For a decade, from 2000 to 2010, no publication addressed the subject of smart city risks.

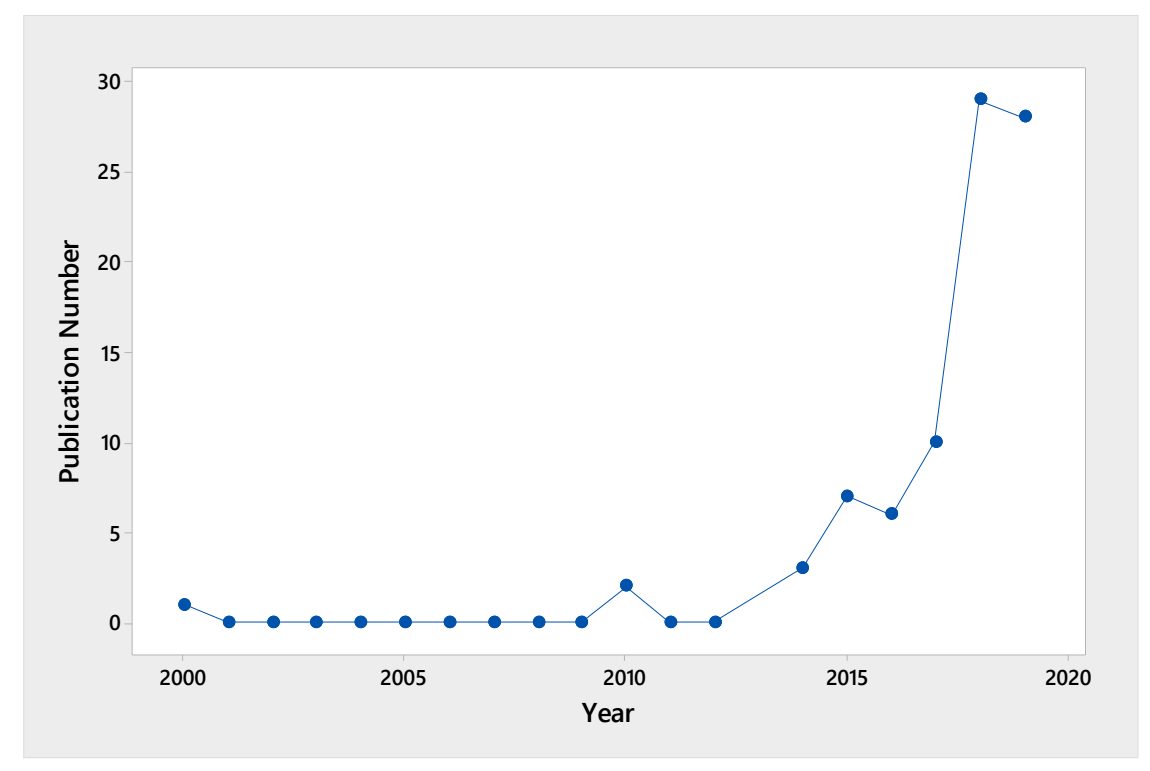

Figure 2. Number of publications, by year.

The selected articles are also very distinct in terms of their context, and a total of 25 different countries were identified. The number of studies in each country was counted, and the results show that more than $42 \%$ of the papers were published in the UK (14 articles), US (13 articles), and China (10 articles).

Table 2 also indicates that the research methods in the included papers are varied. This variation is because the studies were included subject to the inclusion criteria, regardless of their research methodology. The analysis of the results, which is illustrated in Figure 3, shows that $36 \%$ of the identified articles used empirical methods, while 33\% utilized theoretical methods. Qualitative methods are presented in $21 \%$ of the studies, and quantitative and mixed methods, respectively, are found in $5 \%$ and $4 \%$. 


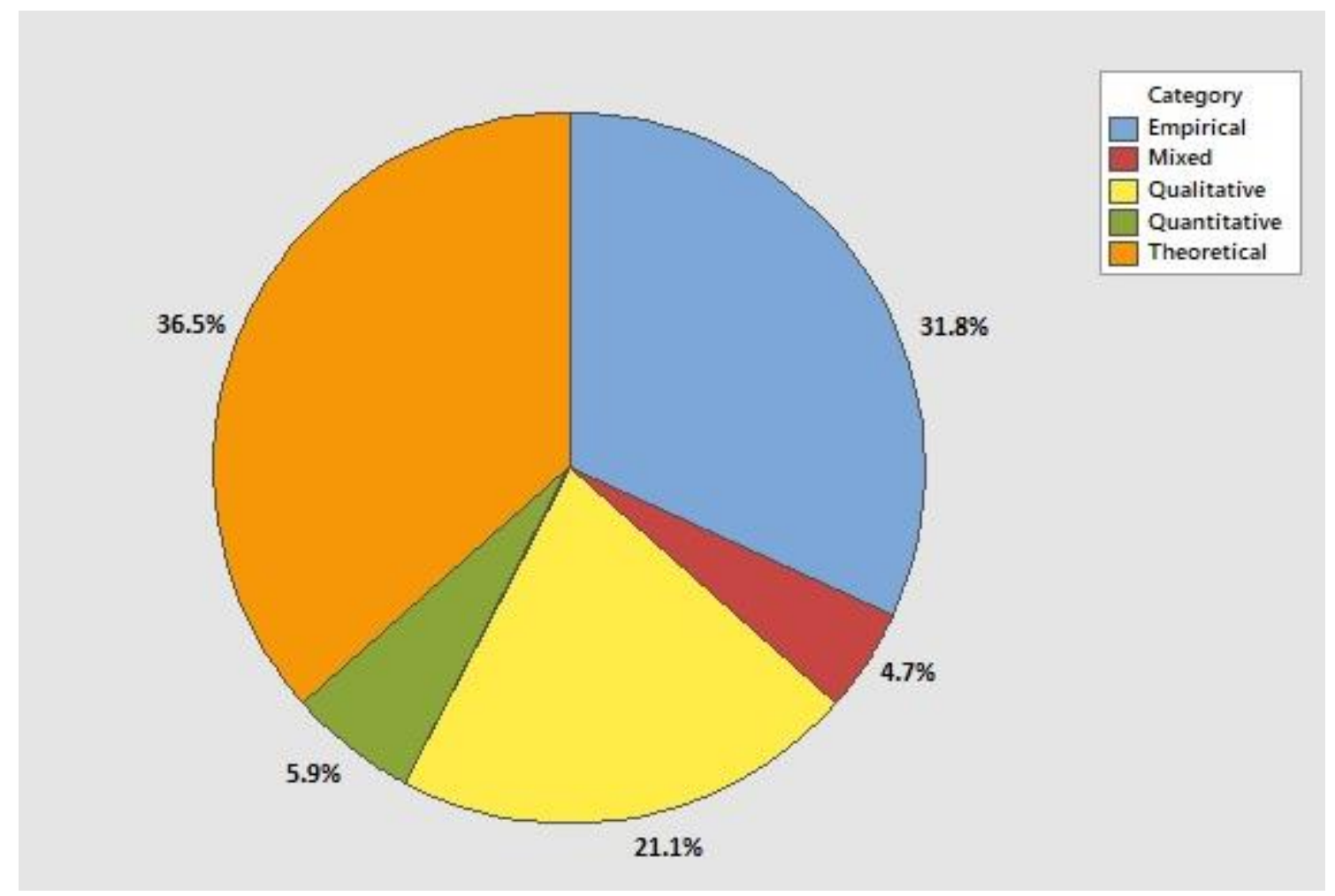

Figure 3. Research methods.

\subsection{Thematic Analysis}

The selected publications determine different types of risks for smart-city development. Vidiasova, Cronemberger, and Vidiasov [122] categorized smart city risk factors as organizational, social, and technological. Table 3 represents the risk factors under each category.

Table 3. Smart-city critical risk factors (modified from Vidiasova et al. [122]).

\begin{tabular}{cc}
\hline $\begin{array}{c}\text { Organizational } \\
\text { Risks }\end{array}$ & Resistance to the Citizens' Participation in Political Decision-Making \\
\hline Absence of required competencies of authorities in a smart city \\
Over technologized organizations \\
Complication of city-management processes
\end{tabular}

Accordingly, the identified articles were categorized thematically under three different groups, including "organizational risks", "social risks", and "technological risks", based on the type of risk that they address. The majority of the papers, which accounts for $52 \%$ of the studies, investigates technological risks, while only $16 \%$ of the articles consider social risks in smart-city development programs. The remaining articles, comprising 32\% of the total, address organizational risks. 
Organizational risks are most frequently mentioned in the studies conducted in China $(n=6)$, the US $(n=4)$, and India $(n=4)$ While social risks are mostly discussed in the UK $(n=3)$ and Italy $(n=3)$, technological risks are mainly addressed by the UK $(n=9)$ and the US $(n=7)$.

\subsubsection{Organizational Risks}

The first theme focuses on organizational risks for smart-city development programs, and 28 papers were identified within this theme. This group of papers is divided into two subcategories. The first subset introduces different types of potential hazards to smart-city governance, strategies, decision-making, coordination processes, and business environments. For example, Brous, Janssen and Herder [105] examine the risks associated with the adoption of the Internet of Things (IoT) in smart-city organizations. They identify a number of organizational risks, such as "high implementation cost", "low-quality service", "lack of sufficient legal framework", and "inaccurate data on which decisions are made". Javidroozi, Shah and Feldman [49] also highlight some additional organizational risks and challenges, including "complexity", "efficiency", "agility and flexibility", "monitoring", and "standardization". Correspondingly, Wu, Zhang, Shen, Mo, and Peng [68] investigate the organizational risks embedded in the development of smart cities with Chinese characteristics and highlight a few risks, mainly including the "incapability of dealing with an emergency" and "lack of independent research on smart cities".

The second subset in this theme includes articles that propose an organizational solution to overcome smart-city risks. De Nicola, Melchiori, and Villani [83] present a framework to deal with risks and consequences of an emergency situation in smart cities, to support decision-makers in developing emergency plans. Similarly, Mustafa and Kar [84] identify and prioritize different risk dimensions, to help smart-city risk managers decide which dimensions of risk are more critical for digital-service delivery in smart cities. They also argue that performance and financial risks are the most significant organizational risks across digital services in smart cities. Safransky [58] proposed a decision-making supporting algorithm, via a case-study simulation, for authorities to identify potential areas of high risk in violence.

\subsubsection{Social Risks}

The second category which focuses on social risks for smart cities is the least researched area, and only 14 publications were identified in this theme. This theme included articles that discuss possible threats of smart cities to individuals, societies, and communities, as well as solutions to mitigate these concerns. For example, Galdon-Clavell [92] argues that citizen empowerment and bottom-up approaches are neglected in smart cities' programs. The author also identifies other problems, including discrimination and uninformed consent. In another study, White [113] challenges the claimed social benefits of smart cities, including their role as a solution for rapid-urbanization social issues. The researcher then asserts that smart cities do not tend to address any causes of these social problems. Trivellato [76] also investigates social sustainability risks in smart cities and identifies a low level of citizen participation and involvement in urban decision-making processes as one of the social risks for smart cities. McGuire [39] goes even further and warns about stupefaction and stultification in smart cities. Stupefaction is defined as the risk of losing control over how we use technology, while stultification is described as the risk of new technologies making citizens more stupid because people might lose their ability to engage in inference and reasoning.

Another subset of publications in this category proposes a method, tool, or technique to manage social risks in smart cities. Di Bella et al. [73] develop a multi-indicator approach for measuring urban crimes in smart cities. This study categorizes different landscapes of public safety and risk of crime into five groups of indicators, namely crime count, population-based crime rate, risk-based crime rate, crime density, and crime-location proportions. Grimaldi et al. [96] also develop a method to manage the opening of new shops to decrease the risk of uniformity in communities and gentrification in 
smart cities. Their model is based on some business and social criteria, such as the flow of people, the localization of shops, and the neighborhood's culture.

\subsubsection{Technological Risks}

The third theme includes 45 publications that address technological risks for smart cities and is the most abundantly researched area among the identified literatureWhile the articles in this group mainly focus on cybersecurity, there is a secondary subset that considers other types of technological risks for smart cities. Vassilaras and Yovanof [97] provide an overview of some technological risks and challenges for smart cities, including cybersecurity and privacy, as well as interoperability among different technologies. Subsequently, Zhu and Zuo [64] present a system security mode to unravel the cybersecurity problems of smart cities. The study suggests some measures to consolidate information security in smart cities, including enhancing citizens' information security literacy, improving information management regulations, and reinforcing physical equipment and infrastructure. Kitchin and Dodge [48] investigate the current status of information security in smart cities, as well as existing mitigation strategies, and then propose a set of systematic interventions to enhance cybersecurity. The suggested solutions include security-by-design, corrective security patching and replacement, the establishment of a security emergency response team, modification of the procedures of procurement, and continuing professional development.

The second category of publications in this theme addresses technological risks other than cybersecurity challenges. Lee et al. [87] introduce a new smart water grid to decrease the water infrastructures' failures in smart cities. In this study, ICT and water-management solutions are integrated to increase water security, as well as the safety of water quality. In another study, Bartoli et al. [74] created an IT platform to monitor, predict, and manage technical risks in smart cities. The proposed system integrates ICT infrastructures and analysis methods to manage the flow of information among first responders, city authorities, and smart city residents. In another study, Spiliotis et al. [99] designed a framework to track the performance of photovoltaic systems, to minimize the risk of malfunction and mitigate the effects of uncertainty related to the monitoring and maintenance of photovoltaic systems in a smart city.

\subsubsection{Co-Related Themes}

While these three themes may seem independent of each other on the surface, there are some overlaps among them. The identified articles can be primarily categorized into one of the "Organizational Risks", "Social Risks", or "Technological Risks" themes; however, they can be further classified into one of three co-related themes: (1) "Digital Transformation Risks" [123], (2) "Socio-Technical Risks" [124], and (3) "Corporate Social Responsibility Risks" [125]. Figure 4 illustrates these overlaps among smart-city risks.

The results of this thematic analysis revealed that the most frequent overlapping theme is "Socio-Technical Risks" (see Table 4). Not everyone is proficient in utilizing digital technologies or fully aware of the available smart technologies, as digital illiteracy remains present in current society, and not everyone is given sufficient access to digital technologies. As a result, there is a high probability that technology-vulnerable people will be neglected and thus be unable to receive the full benefits of a smart city. As socio-technical systems comprise both human and technological elements, there are corresponding dynamic "Socio-Technical Risks" for these systems [124]. Technological and organizational factors are linked together by the digital transformation concept, as not all organizations are ready to adopt new changes or are aware of the need for technological changes. Furthermore, not every business is able to invest in advanced digital technologies to change its current processes and older digital technologies. Thus, the correlated risk can be considered "Digital Transformation Risk" [123]. Finally, corporate social responsibility is at the intersection of the organizational and social aspects, and the risks at this conjunction are defined as "Corporate Social Responsibility Risks" [125]. The cutting-edge technologies driving current cities to smart cities have been developed 
by various research institutions and commercial corporations. These corporations have a degree of responsibility for the social consequences of their activities, which can be perceived as "Corporate Social Responsibility Risk".

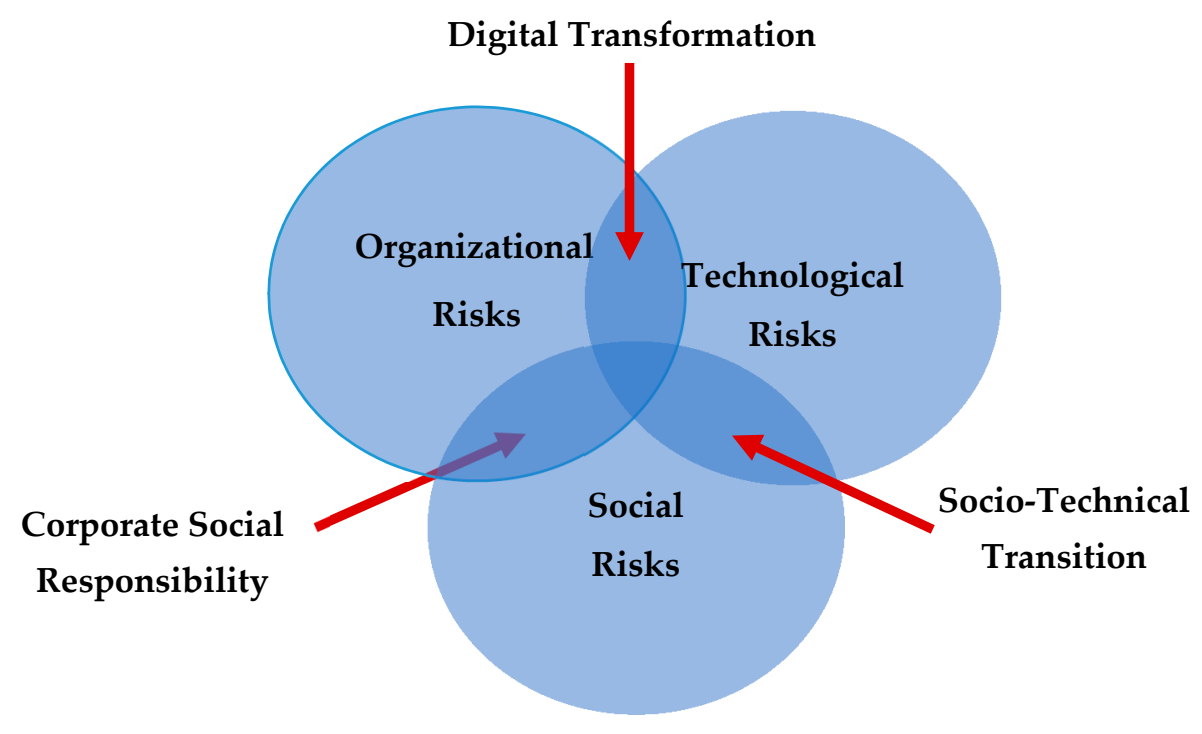

Figure 4. Co-relations between smart-city risks.

Table 4. Publications under overlap themes.

\begin{tabular}{lccccc}
\hline Publication & $\begin{array}{c}\text { Organizational } \\
\text { Risks }\end{array}$ & $\begin{array}{c}\text { Technological } \\
\text { Risks }\end{array}$ & $\begin{array}{c}\text { Social } \\
\text { Risks }\end{array}$ & Overlapping Theme/Risk \\
\hline 1 & Coccossis et al. [98] & $\sqrt{ }$ & & $\sqrt{ }$ & Corporate Social Responsibility \\
2 & Di Bella et al. [73] & $\sqrt{ }$ & & $\sqrt{ }$ & Corporate Social Responsibility \\
Corporate Social Responsibility
\end{tabular}

The $\sqrt{ }$ specifies the risk categories of the papers.

\section{Discussion}

This systematic review shows that "Technological Risks" is the most commonly researched theme, while social risk is the least studied area. Since some of the articles belonged to more than one theme, they were further classified into the overlapping themes of "Corporate Social Responsibility Risks", 
"Digital Transformation Risks", and "Socio-Technical Risks". Among these categories, "Socio-Technical Risks" was the most frequent theme.

Although the first article to address smart-city risks was published in 2000, no paper on this topic was published between 2000 and 2010. In contrast to the significant promotion of smart cities within the ICT industry, only a few scholars paid attention to smart-city risks until 2010. This is because the effects of any changes in urban systems take considerable time to appear [126]. Moreover, the proper establishment of smart-city research as a new scientific area goes back to 2009 [127]. Therefore, the implementation of well-established knowledge areas, such as risk management, to the smart city concept was delayed until 2010, making this topic a relatively new research discipline.

The review shows that the United Kingdom (UK) has the highest number of studies in the area of smart-city risk. This result was predictable, since both the first smart city, Bletchley Park [128], and the most advanced smart city, London [129], are located in the UK. Furthermore, the UK has the highest number of smart cities among European countries [130]. All of these factors can reasonably explain the large number of publications in the UK.

The most obvious finding to emerge from this review is that technological risks have been widely investigated in the literature, while social risks have been largely overlooked, even though Vidiasova et al. [122] noted that social risks for smart cities are as significant as technological risks. Technological risks may be overemphasized because technology is the main driver of smart-city development [14], and the concept is primarily promoted by leading ICT corporations, such as IBM, Cisco, and Siemens [131]. An alternative explanation is that, while technical challenges are detectible during the implementation stage, the social effects of smart cities might take considerably more time to appear in societies. Therefore, social risks have not yet emerged as a critical issue over an extended period and, consequently, have not been investigated as frequently as technological risks.

Another important finding is that, along with the UK, Italy has the highest number of studies on smart-city social risks. This result can be explained by the fact that Italian citizens are actively engaged with city governance and decision-making processes, and ICT technology is utilized only to enhance residents' quality of life and resolve social problems [130]. The government has also implemented various programs to reduce social risks in their smart cities [130]. These attributes highlight the significance of social aspects in Italian smart cities, so it is hardly surprising that Italy has the highest number of articles on the "social risk" theme.

\section{Conclusions and Future Work}

The integration of risk management into smart-city strategic plans is vital, as transitioning from a traditional to a smart city is a complex and uncertain process. Various reviews have been conducted on different domains of the smart city. However, there has not yet been a comprehensive overview of the current publications on smart-city risks. Therefore, this study set out to explore the existing literature, to identify the origin, trends, and types of risks in smart-city research studies over the past two decades. Through a systematic literature review, this study identified 85 articles related to smart-city risks. The selected articles were analyzed, interpreted, and categorized, to recognize their common and overlapping themes.

The results reveal that risk is a relatively new topic in the smart-city discipline, which is mostly discussed in the context of countries that have the highest number of existing smart cities. This review determined the three different categories for smart cities: technological, organizational, and social risks. It also identified some overlapping groups, including digital transformation, socio-technical, and corporate social responsibility risks. The review findings suggest that, although various studies address smart-city technological risks, little focus is given to the related social aspects. The reason for the lack of such studies is partially because the primary driving force of smart cities is the technology promoted by major ICT corporations. An alternative explanation is that, unlike technical problems, social issues take a long time to appear. Another major finding is that studies from countries that have a long history of smart cities, such as the UK and Italy, have paid more attention to these social risks. 
This study provides a comprehensive overview of the risk subject matter in the smart-city literature and a significant understanding of smart-city risks. It establishes a practical guide for urban authorities to use in their governance processes and also lays the groundwork for future investigations in the field. Future research should focus on exploring the relevant social risks and mitigation strategies, to assist governments in their decision-making processes. Furthermore, socio-technical risks need further examination, to find the best match between the technological and social components of a smart city.

A limitation of this review is that only peer-reviewed articles were selected. Secondly, this study reviewed only publications under the smart-city domain in the Scopus and Web of Science databases. Finally, although the focus of this review was on risks, it does not mean that other aspects of smart cities are fully understood by the research community.

Author Contributions: Conceptualization, S.S.; methodology, S.S. and T.H.D.N.; resources, T.H.D.N.; validation, T.H.D.N. and K.P.K.; visualization, K.P.K.; writing-original draft, S.S.; writing-review and editing, K.P.K., T.H.D.N., and T.M. All authors have read and agreed to the published version of the manuscript.

Funding: This research received no external funding.

Conflicts of Interest: The authors declare no conflict of interest.

\section{References}

1. Seto, K.C.; Parnell, S.; Elmqvist, T. A Global Outlook on Urbanization. In Urbanization, Biodiversity and Ecosystem Services: Challenges and Opportunities; Springer: Dordrecht, the Netherlands, 2013; pp. 1-12.

2. Malik, S.; Wahid, J. Rapid urbanization: Problems and challenges for adequate housing in Pakistan. J. Sociol. Soc. Work. 2014, 2, 87-110. [CrossRef]

3. Vein, C. Why We Need Smart Cities. Available online: https://www.digitalpulse.pwc.com.au/why-we-needsmart-cities/ (accessed on 25 October 2019).

4. Pérez, L.M.; Oltra-Badenes, R.; Oltra Gutiérrez, J.V.; Gil-Gómez, H. A Bibliometric Diagnosis and Analysis about Smart Cities. Sustainability 2020, 12, 6357. [CrossRef]

5. Washburn, D.; Sindhu, U.; Balaouras, S.; Dines, R.A.; Hayes, N.; Nelson, L.E. Helping CIOs understand "smart city" initiatives. Growth 2009, 17, 1-17.

6. Herraiz-Faixó, F. Driving Municipal Recycling by Connecting Digital Value Endpoints in Smart Cities. Sustainability 2020, 12, 6433. [CrossRef]

7. Rana, N.P.; Luthra, S.; Mangla, S.K.; Islam, R.; Roderick, S.; Dwivedi, Y.K. Barriers to the development of smart cities in Indian context. Inf. Syst. Front. 2019, 21, 503-525. [CrossRef]

8. Nam, T.; Pardo, T.A. Conceptualizing smart city with dimensions of technology, people, and institutions. In Proceedings of the 12th Annual International Digital Government Research Conference: Digital Government Innovation in Challenging Times, College Park, MD, USA, 12-15 June 2011; pp. 282-291.

9. Van den Bergh, J.; Viaene, S. Key challenges for the smart city: Turning ambition into reality. In Proceedings of the 2015 48th Hawaii International Conference on System Sciences, Kauai, HI, USA, 5-8 January 2015; pp. 2385-2394.

10. Monfaredzadeh, T.; Krueger, R. Investigating social factors of sustainability in a smart city. Procedia Eng. 2015, 118, 1112-1118. [CrossRef]

11. Giffinger, R.; Pichler-Milanović, N. Smart Cities: Ranking of European Medium-Sized Cities; Centre of Regional Science, Vienna University of Technology: Vienna, Austria, 2007.

12. Yigitcanlar, T.; Kamruzzaman, M.; Buys, L.; Ioppolo, G.; Sabatini-Marques, J.; da Costa, E.M.; Yun, J.J. Understanding 'smart cities': Intertwining development drivers with desired outcomes in a multidimensional framework. Cities 2018, 81, 145-160. [CrossRef]

13. Dameri, R.P.; Garelli, R. Measuring business benefits and performance in smart cities. In Proceedings of the European Conference on Innovation and Entrepreneurship, Belfast, UK, 18-19 September 2014; p. 137.

14. Dameri, R.P.; Rosenthal-Sabroux, C. Smart City and Value Creation. In Smart City; Springer: Cham, Switzerland, 2014; pp. 1-12.

15. Belanche, D.; Casaló, L.V.; Orús, C. City attachment and use of urban services: Benefits for smart cities. Cities 2016, 50, 75-81. [CrossRef] 
16. Gordon, L.W.; McAleese, G.W. Resilience and Risk Management in Smart Cities. Available online: https: //cip.gmu.edu/2017/07/06/resilience-risk-management-smart-cities/ (accessed on 10 March 2020).

17. Geels, F.W. Ontologies, socio-technical transitions (to sustainability), and the multi-level perspective. Res. Policy 2010, 39, 495-510. [CrossRef]

18. British Standards Institution. Smart city Framework. Guide to Establishing Strategies for Smart Cities and Communities; BSI: London, UK, 2014; Volume PAS 181.

19. International Organization for Standardization. Sustainable Cities and Communities_Guidance on Establishing Smart City Operating Models for Sustainable Communities; ISO: London, UK, 2018; Volume ISO.

20. Lim, Y.; Edelenbos, J.; Gianoli, A. Identifying the results of smart city development: Findings from systematic literature review. Cities 2019, 95, 102397. [CrossRef]

21. Ruhlandt, R.W.S. The governance of smart cities: A systematic literature review. Cities 2018, 81, 1-23. [CrossRef]

22. Purnomo, F.; Prabowo, H. Smart city indicators: A systematic literature review. J. Telecommun. Electron. Comput. Eng. 2016, 8, 161-164.

23. Javadzadeh, G.; Rahmani, A.M. Fog computing applications in smart cities: A systematic survey. Wirel. Netw. 2020, 26, 1433-1457. [CrossRef]

24. Thyer, B. The Handbook of Social Work Research Methods; Sage Publications: Newbury Park, CA, USA, 2009.

25. Buchanan, D.A.; Bryman, A. The SAGE Handbook of Organizational Research Methods/edited by David A. Buchanan and Alan Bryman; Sage Publications: Los Angeles, CA, USA, 2011.

26. Jesson, J.; Matheson, L.; Lacey, F.M. Doing Your Literature Review: Traditional and Systematic Techniques; Sage: London, UK, 2011.

27. Ismagilova, E.; Hughes, L.; Dwivedi, Y.K.; Raman, K.R. Smart cities: Advances in research-An information systems perspective. Int. J. Inf. Manag. 2019, 47, 88-100. [CrossRef]

28. Cubillos-González, R.-A.; Tiberio Cardoso, G. Clean Technology Transfer and Innovation in Social Housing Production in Brazil and Colombia. A Framework from a Systematic Review. Sustainability 2020, 12, 1335. [CrossRef]

29. Tight, M. Chapter 7 | Systematic Reviews and Meta-Analyses. In Documentary Research in the Social Sciences; Tight, M., Ed.; SAGE Publications Ltd.: London, UK, 2019. [CrossRef]

30. Gupta, P.; Chauhan, S.; Jaiswal, M. Classification of smart city research-a descriptive literature review and future research agenda. Inf. Syst. Front. 2019, 21, 661-685. [CrossRef]

31. Web of Science Group. Confident Research Begins Here. Available online: https://clarivate.com/webofsciencegroup/ solutions/web-of-science/ (accessed on 18 March 2020).

32. Berardi, U.; Albino, V.; Dangelico, R. Smart cities: Definitions, dimensions, and performance. J. Urban Technol. 2015, 22, 3-21.

33. O'Brien, A.M.; Mc Guckin, C. The Systematic Literature Review Method: Trials and Tribulations of Electronic Database Searching at Doctoral Level; SAGE Publications, Ltd.: London, UK, 2016.

34. Gough, D.; Oliver, S.; Thomas, J. Learning From Research: Systematic Reviews For. Informing Policy Decisions-A Quick Guide; University of London: London, UK, 2013.

35. Okoli, C.; Schabram, K. A Guide to Conducting a Systematic Literature Review of Information Systems Research; SSRN: Montreal, QC, Canada, 2010.

36. Bearman, M.; Dawson, P. Qualitative synthesis and systematic review in health professions education. Med. Educ. 2013, 47, 252-260. [CrossRef]

37. Viitanen, J.; Kingston, R. Smart cities and green growth: Outsourcing democratic and environmental resilience to the global technology sector. Environ. Plan. A 2014, 46, 803-819. [CrossRef]

38. Beart, P. Evolving to an ecosystem of lot applications. J. Inst. Telecommun. Prof. 2015, 9, 16-20.

39. Mehmood, R.; Meriton, R.; Graham, G.; Hennelly, P.; Kumar, M. Exploring the influence of big data on city transport operations: A Markovian approach. Int. J. Oper.Prod. Manag. 2017, 37, 75-104. [CrossRef]

40. Vasileva, R.; Rodrigues, L.; Hughes, N.; Greenhalgh, C.; Goulden, M.; Tennison, J. What smart campuses can teach us about smart cities: User experiences and open data. Information 2018, 9, 251. [CrossRef]

41. McGuire, M. Beyond flatland: When smart cities make stupid citizens. City Territ. Archit. 2018, 5, 22. [CrossRef]

42. Ahmad, F.; Adnane, A.; Franqueira, V.N.; Kurugollu, F.; Liu, L. Man-in-the-middle attacks in vehicular ad-hoc networks: Evaluating the impact of attackers' strategies. Sensors 2018, 18, 4040. [CrossRef] 
43. Amankwaa, E.F.; Blay, K.B. Cities at risk? Exploring the synergies between smartphones and everyday vulnerabilities. Cities 2018, 83, 129-139. [CrossRef]

44. Ahmad, F.; Franqueira, V.N.L.; Adnane, A. TEAM: A Trust Evaluation and Management Framework in Context-Enabled Vehicular Ad-Hoc Networks. IEEE Access 2018, 6, 28643-28660. [CrossRef]

45. Alandjani, G. Features and Potential Security Challenges for IoT Enabled Devices in Smart City Environment. Int. J. Adv. Comput. Sci. Appl. 2018, 9, 231-238. [CrossRef]

46. Vitunskaite, M.; He, Y.; Brandstetter, T.; Janicke, H. Smart cities and cyber security: Are we there yet? A comparative study on the role of standards, third party risk management and security ownership. Comput. Secur. 2019, 83, 313-331. [CrossRef]

47. Urquhart, L.; Schnädelbach, H.; Jäger, N. Adaptive architecture: Regulating human building interaction. Int. Rev. Law Comput. Technol. 2019, 33, 3-33. [CrossRef]

48. Kitchin, R.; Dodge, M. The (in) security of smart cities: Vulnerabilities, risks, mitigation, and prevention. J. Urban Technol. 2019, 26, 47-65. [CrossRef]

49. Javidroozi, V.; Shah, H.; Feldman, G. A framework for addressing the challenges of business process change during enterprise systems integration. Bus. Process Manag. J. 2019, 26, 463-488. [CrossRef]

50. Goldhill, S. The infrastructure of tolerance. Philos. Soc. Crit. 2019, 45, 516-526. [CrossRef]

51. Avgerou, A.; Nastou, P.E.; Nastouli, D.; Pardalos, P.; Stamatiou, Y.C. On the Deployment of Citizens' Privacy Preserving Collective Intelligent eBusiness Models in Smart Cities. Int. J. Secur. Appl. 2016, 10, 171-184. [CrossRef]

52. Saaty, T.; De Paola, P. Rethinking Design and Urban Planning for the Cities of the Future. Buildings 2017, 7, 76. [CrossRef]

53. Li, Z.; Shahidehpour, M. Deployment of cybersecurity for managing traffic efficiency and safety in smart cities. Electr. J. 2017, 30, 52-61. [CrossRef]

54. Shuva, G.A.G. A semi-Markov model for post-earthquake emergency response in a smart city. J. Control Theory Appl. 2017, 15, 13-25. [CrossRef]

55. Michelfelder, D.P. Risk, disequilibrium, and virtue. Technol. Soc. 2018, 52, 32-38. [CrossRef]

56. Falco, G.; Viswanathan, A.; Caldera, C.; Shrobe, H. A Master Attack Methodology for an AI-Based Automated Attack Planner for Smart Cities. IEEE Access 2018, 6, 48360-48373. [CrossRef]

57. Soyata, T.; Habibzadeh, H.; Ekenna, C.; Nussbaum, B.; Lozano, J. Smart city in crisis: Technology and policy concerns. Sustain. Cities Soc. 2019, 50, 101566. [CrossRef]

58. Safransky, S. Geographies of Algorithmic Violence: Redlining the Smart City. Int. J. Urban Reg. Res. 2019, 44, 200-218. [CrossRef]

59. Means, A.J. Platform Urbanism, Creativity, and the New Educational Futurism. Educ. Theory 2019, 69, 205-223. [CrossRef]

60. He, B.Y.; Chow, J.Y.J. Optimal privacy control for transport network data sharing. Transp. Res. Procedia 2019, 38, 792-811. [CrossRef]

61. Eskridge, M. Privacy and Security Data Governance: Surveillance Mechanisms and Resilience Risks of Smart City Technologies. Contemp. Read. Law Soc. Justice 2019, 11, 63. [CrossRef]

62. Chen, J.; Zhu, Q. Interdependent Strategic Security Risk Management With Bounded Rationality in the Internet of Things. IEEE Trans. Inf. Forensics Secur. 2019, 14, 2958-2971. [CrossRef]

63. Al Shidhani, A.A. Cyber Defense Maturity Levels and Threat Models for Smart Cities. Int. J. Inf. Secur. Priv. 2019, 13, 32-46. [CrossRef]

64. Zhu, Y.; Zuo, J. Research on security construction of smart city. Int. J. Smart Home 2015, 9, 197-204. [CrossRef]

65. Xu, J.; Zhao, S.-J.; Zhou, F.-C. Privacy Protection Model Based on Digital Envelope and Dummies for Location-Based Services. J. Inf. Sci. Eng. 2017, 33, 965-978.

66. Hasan, A.; Jiang, Q.; Li, C. An effective grouping method for privacy-preserving bike sharing data publishing. Future Internet 2017, 9, 65. [CrossRef]

67. Anwar, B.; Xiao, Z.; Akter, S.; Rehman, R.-U. Sustainable Urbanization and Development Goals Strategy through Public-Private Partnerships in a South-Asian Metropolis. Sustainability 2017, 9, 1940. [CrossRef]

68. Wu, Y.; Zhang, W.; Shen, J.; Mo, Z.; Peng, Y. Smart city with Chinese characteristics against the background of big data: Idea, action and risk. J. Clean. Prod. 2018, 173, 60-66. [CrossRef]

69. Wang, J.; Ding, S.; Song, M.; Fan, W.; Yang, S. Smart community evaluation for sustainable development using a combined analytical framework. J. Clean. Prod. 2018, 193, 158-168. [CrossRef] 
70. Li, X.; Li, H.; Sun, B.; Wang, F. Assessing information security risk for an evolving smart city based on fuzzy and grey FMEA. J. Intell. Fuzzy Syst. 2018, 34, 2491-2501. [CrossRef]

71. Aung, N.; Zhang, W.; Dhelim, S.; Ai, Y. Accident prediction system based on hidden markov model for vehicular ad-hoc network in urban environments. Information 2018, 9, 311. [CrossRef]

72. Elahi, H.; Wang, G.; Peng, T.; Chen, J. On Transparency and Accountability of Smart Assistants in Smart Cities. Appl. Sci. 2019, 9, 5344. [CrossRef]

73. Di Bella, E.; Corsi, M.; Leporatti, L. A multi-indicator approach for smart security policy making. Soc. Indic. Res. 2015, 122, 653-675. [CrossRef]

74. Bartoli, G.; Fantacci, R.; Gei, F.; Marabissi, D.; Micciullo, L. A novel emergency management platform for smart public safety. Int. J. Commun. Syst. 2015, 28, 928-943. [CrossRef]

75. Comodi, G.; Caresana, F.; Salvi, D.; Pelagalli, L.; Lorenzetti, M. Local promotion of electric mobility in cities: Guidelines and real application case in Italy. Energy 2016, 95, 494-503. [CrossRef]

76. Trivellato, B. How can 'smart'also be socially sustainable? Insights from the case of Milan. Eur. Urban Reg. Stud. 2017, 24, 337-351. [CrossRef]

77. Beretta, I. The social effects of eco-innovations in Italian smart cities. Cities 2018, 72, 115-121. [CrossRef]

78. Anjum, A.; Ahmed, T.; Khan, A.; Ahmad, N.; Ahmad, M.; Asif, M.; Reddy, A.G.; Saba, T.; Farooq, N. Privacy preserving data by conceptualizing smart cities using MIDR-Angelization. Sustain. Cities Soc. 2018, 40, 326-334. [CrossRef]

79. De Nicola, A.; Melchiori, M.; Villani, M.L. Creative design of emergency management scenarios driven by semantics: An application to smart cities. Inf. Syst. 2019, 81, 21-48. [CrossRef]

80. Sharma, D.; Singh, S. Instituting environmental sustainability and climate resilience into the governance process: Exploring the potential of new urban development schemes in India. Int. Area Stud. Rev. 2016, 19, 90-103. [CrossRef]

81. Hayat, P. Smart Cities: A global perspective. India Q. 2016, 72, 177-191. [CrossRef]

82. Dhyani, S.; Lahoti, S.; Khare, S.; Pujari, P.; Verma, P. Ecosystem based Disaster Risk Reduction approaches (EbDRR) as a prerequisite for inclusive urban transformation of Nagpur City, India. Int. J. Disaster Risk Reduct. 2018, 32, 95-105. [CrossRef]

83. Bashir, A.; Mir, A.H. Internet of things security issues, threats, attacks and counter measures. Int. J. Comput. Digit. Syst. 2018, 7, 111-120. [CrossRef]

84. Mustafa, S.Z.; Kar, A.K. Prioritization of multi-dimensional risk for digital services using the generalized analytic network process. Digit. Policy Regul. Gov. 2019, 21, 146-163. [CrossRef]

85. Malik, V.; Singh, S. Security risk management in IoT environment. J. Discret. Math. Sci. Cryptogr. 2019, 22, 697-709. [CrossRef]

86. Shin, D.H. Ubiquitous computing acceptance model: End user concern about security, privacy and risk. Int. J. Mob. Commun. 2010, 8, 169-186. [CrossRef]

87. Lee, S.W.; Sarp, S.; Jeon, D.J.; Kim, J.H. Smart water grid: The future water management platform. Desalin. Water Treat. 2015, 55, 339-346. [CrossRef]

88. Ullah, I.; Fayaz, M.; Kim, D. Analytical modeling for underground risk assessment in smart cities. Appl. Sci. 2018, 8, 921. [CrossRef]

89. Park, K. A Risk Management Model for Sustainable Smart City. Int. J. Adv. Sci. Technol. 2018, 8. [CrossRef]

90. Fayaz, M.; Ullah, I.; Kim, D.-H. Underground risk index assessment and prediction using a simplified hierarchical fuzzy logic model and kalman filter. Processes 2018, 6, 103. [CrossRef]

91. Lee, E. What does Citizen Petition Call for Smart City? Focus on Residents' Safety and Crisis Perception. J. Adv. Res. Dyn. Control Syst. 2019, 11, 1316-1319.

92. Galdon-Clavell, G. (Not so) smart cities?: The drivers, impact and risks of surveillance-enabled smart environments. Sci. Public Policy 2013, 40, 717-723. [CrossRef]

93. Sánchez Bernabeu, J.M.; Berna-Martinez, J.V.; Maciá Pérez, F. Smart Sentinel: Monitoring and Prevention System in the Smart Cities; Praise Worthy Prize: Rome, Italy, 2014.

94. Rebollo-Monedero, D.; Bartoli, A.; Hernández-Serrano, J.; Forné, J.; Soriano, M. Reconciling privacy and efficient utility management in smart cities. Trans. Emerg. Telecommun. Technol. 2014, 25, 94-108. [CrossRef]

95. Mulero, R.; Almeida, A.; Azkune, G.; Abril-Jiménez, P.; Waldmeyer, M.T.A.; Castrillo, M.P.; Patrono, L.; Rametta, P.; Sergi, I. An IoT-aware approach for elderly-friendly cities. IEEE Access 2018, 6, 7941-7957. [CrossRef] 
96. Grimaldi, D.; Fernandez, V.; Carrasco, C. Heuristic for the localization of new shops based on business and social criteria. Technol. Forecast. Soc. Chang. 2019, 142, 249-257. [CrossRef]

97. Vassilaras, S.; Yovanof, G.S. Wireless innovations as enablers for complex \& dynamic artificial systems. Wirel. Pers. Commun. 2010, 53, 365-393.

98. Coccossis, H.; Delladetsimas, P.-M.; Niavis, S. The challenge of incorporating smart city activities in medium-size cities: The case of Greece. Int. J. Serv. Technol. Manag. 2017, 23, 381-402. [CrossRef]

99. Spiliotis, E.; Legaki, N.Z.; Assimakopoulos, V.; Doukas, H.; El Moursi, M.S. Tracking the performance of photovoltaic systems: A tool for minimising the risk of malfunctions and deterioration. IET Renew. Power Gener. 2018, 12, 815-822. [CrossRef]

100. Moustaka, V.; Theodosiou, Z.; Vakali, A.; Kounoudes, A.; Anthopoulos, L.G. Enhancing social networking in smart cities: Privacy and security borderlines. Technol. Forecast. Soc. Chang. 2019, 142, 285-300. [CrossRef]

101. Vu, K.; Hartley, K. Promoting smart cities in developing countries: Policy insights from Vietnam. Telecommun. Policy 2018, 42, 845-859. [CrossRef]

102. Lim, H.S.M.; Taeihagh, A. Autonomous vehicles for smart and sustainable cities: An in-depth exploration of privacy and cybersecurity implications. Energies 2018, 11, 1062. [CrossRef]

103. Lim, H.S.M.; Taeihagh, A. Algorithmic decision-making in AVs: Understanding ethical and technical concerns for smart cities. Sustainability 2019, 11, 5791. [CrossRef]

104. Ranchordás, S.; Goanta, C. The New City Regulators: Platform and Public Values in Smart and Sharing Cities. Comput. Law Secur. Rev. 2020, 36, 105375. [CrossRef]

105. Brous, P.; Janssen, M.; Herder, P. The dual effects of the Internet of Things (IoT): A systematic review of the benefits and risks of IoT adoption by organizations. Int. J. Inf. Manag. 2020, 51, 101952. [CrossRef]

106. Seto, Y. Application of privacy impact assessment in the smart city. Electron. Commun. Jpn. 2015, 98, 52-61. [CrossRef]

107. Takayuki, S.; Yusuke, M.; Toshiki, K. Security Requirements and Technologies for Smart City IoT. City Management Technologies. NEC Tech. J. 2018, 12, 54-57.

108. Norton, J.; Atun, F.; Dandoulaki, M. Exploring issues limiting the use of knowledge in disaster risk reduction. TeMA J. Land Use Mobil. Environ. 2015, 8, 135-154.

109. Thibaud, M.; Chi, H.; Zhou, W.; Piramuthu, S. Internet of Things (IoT) in high-risk Environment, Health and Safety (EHS) industries: A comprehensive review. Decis. Support Syst. 2018, 108, 79-95. [CrossRef]

110. Jaïdi, F.; Labbene Ayachi, F.; Bouhoula, A. A methodology and toolkit for deploying reliable security policies in critical infrastructures. Secur. Commun. Netw. 2018, 2018, 7142170. [CrossRef]

111. Bennati, S.; Dusparic, I.; Shinde, R.; Jonker, C.M. Volunteers in the smart city: Comparison of contribution strategies on human-centered measures. Sensors 2018, 18, 3707. [CrossRef]

112. Leszczynski, A. Speculative futures: Cities, data, and governance beyond smart urbanism. Environ. Plan. A Econ. Space 2016, 48, 1691-1708. [CrossRef]

113. White, J.M. Anticipatory logics of the smart city's global imaginary. Urban Geogr. 2016, 37, 572-589. [CrossRef]

114. Pető, R.; Tokody, D. Building and Operating a Smart City. Interdiscip. Descr. Complex Syst. 2019, 17, 476-484. [CrossRef]

115. Krämer, M.; Frese, S.; Kuijper, A. Implementing secure applications in smart city clouds using microservices. Future Gener. Comput. Syst. 2019, 99, 308-320. [CrossRef]

116. Toapanta, M.; Mafla, E.; Orizaga, J. An approach to information security by applying a conceptual model of identities in smart cities projects. J. Eng. Appl. Sci. 2017, 12, 7765-7770.

117. Gulsrud, N.M.; Raymond, C.M.; Rutt, R.L.; Olafsson, A.S.; Plieninger, T.; Sandberg, M.; Beery, T.H.; Jönsson, K.I. 'Rage against the machine'? The opportunities and risks concerning the automation of urban green infrastructure. Landsc. Urban Plan. 2018, 180, 85-92. [CrossRef]

118. Austin, L.M.; Lie, D. Safe Sharing Sites.(Data Law in a Global Digital Economy). N. Y. Univ. Law Rev. 2019, 94, 581-623.

119. Yang, F.; Xu, J. Privacy concerns in China's smart city campaign: The deficit of China's Cybersecurity Law. Asia Pac. Policy Stud. 2018, 5, 533-543. [CrossRef]

120. Steyaert, J. Local governments online and the role of the resident: Government shop versus electronic community. Soc. Sci. Comput. Rev. 2000, 18, 3-16. [CrossRef]

121. Marks, D.F.; Yardley, L. Research Methods for Clinical and Health Psychology; Sage: London, UK, 2004. 
122. Vidiasova, L.; Cronemberger, F.; Vidiasov, E. Risk Factors in Smart City Development in Russia: A Survey. In Proceedings of the International Conference on Electronic Governance and Open Society, Challenges in Eurasia; Springer: Cham, Switzerland, 2018; pp. 26-37.

123. Masuda, Y.; Shirasaka, S.; Yamamoto, S.; Hardjono, T. Risk management for digital transformation in architecture board: A case study on global enterprise. In Proceedings of the 2017 6th IIAI International Congress on Advanced Applied Informatics (IIAI-AAI), Hamamatsu, Japan, 9-13 July 2017; pp. 255-262.

124. Chatzimichailidou, M.M.; Stanton, N.A.; Dokas, I.M. The concept of risk situation awareness provision: Towards a new approach for assessing the DSA about the threats and vulnerabilities of complex socio-technical systems. Saf. Sci. 2015, 79, 126-138. [CrossRef]

125. Kytle, B.; Ruggie, J.G. Corporate Social Responsibility as Risk Management: A Model for Multinationals; Harvard University: Cambridge, MA, USA, 2005.

126. Wikström, A. The Challenge of Change: Planning for social urban resilience.: An analysis of contemporary planning aims and practices. Master's Thesis, Stockholm University, Stockholm, Sweden, 2013.

127. Mora, L.; Bolici, R.; Deakin, M. The first two decades of smart-city research: A bibliometric analysis. J. Urban Technol. 2017, 24, 3-27. [CrossRef]

128. Komninos, N. Intelligent cities: Variable geometries of spatial intelligence. Intell. Build. Int. 2011, 3, $172-188$. [CrossRef]

129. IESE Business School. These Are The Smartest Cities In The World For 2019. Available online: https://www.forbes.com/sites/iese/2019/05/21/these-are-the-smartest-cities-in-the-world-for-2019/ \#4d3a85f11429 (accessed on 2 June 2020).

130. Dameri, R.P.; Benevolo, C.; Veglianti, E.; Li, Y. Understanding smart cities as a glocal strategy: A comparison between Italy and China. Technol. Forecast. Soc. Chang. 2019, 142, 26-41. [CrossRef]

131. Shelton, T.; Zook, M.; Wiig, A. The 'actually existing smart city'. Camb. J. Reg. Econ. Soc. 2015, 8, 13-25. [CrossRef]

Publisher's Note: MDPI stays neutral with regard to jurisdictional claims in published maps and institutional affiliations.

(C) 2020 by the authors. Licensee MDPI, Basel, Switzerland. This article is an open access article distributed under the terms and conditions of the Creative Commons Attribution (CC BY) license (http://creativecommons.org/licenses/by/4.0/). 